\title{
EVALUATION OF PRECEPTORSHIP AND MENTORSHIP CLINICAL LEARNING METHOD ON NURSING STUDENTS' CRITICAL THINKING IN PROVIDING NURSING CARE IN A TEACHING HOSPITAL
}

\author{
Kurniati Puji Lestari $^{\text {a* }}$; Muhamad Jauhar ${ }^{\mathrm{b}}$; Ike Puspitaningrum ${ }^{\mathrm{c}}$; Shobirun ${ }^{\mathrm{d}}$; Iis Sriningsih \\ a,c,de Nursing Department; Poltekkes Kemenkes Semarang ; Tirto Agung street \\ Pedalangan Banyumanik; Semarang 50268, Indonesia \\ ${ }^{b}$ Nursing Department ; Faculty of Health Sciences ; Universitas Muhammadiyah Kudus \\ Ganesha 1 street Purwosari; Kudus 59316; Indonesia
}

\begin{abstract}
The demand for high-quality health services is increasing. It motivates nurses to utilize the best evidence in making decisions. Professional nurses were born from an excellent education. Preceptorship and mentorship clinical learning methods are expected to be able to answer these demands. This study aims to identify the effect of preceptorship and mentorship methods on students' critical thinking skills. The study design applies a quasi-experimental type pretest and post-test with a control group. Twenty-six students were examined as respondents for each intervention and control group, using a purposive sampling technique. The survey took place at a teaching hospital in Semarang, using a student-evidence-based practice questionnaire (validity 0.584-0.904; reliability 0.821) developed by Upton et al.in 2014. The intervention during three weeks with the training stages of clinical advisors, clinical guidance, internalization, and evaluation. Univariate data analysis is described by frequency and percentage (categorical) and mean and SD (numerical). Bivariate data analysis using a paired t-test and independent $t$ test. There was a significant effect of the preceptorship and mentorship methods on students' thinking abilities ( $p$-value $=0.006$ ). Integrated academic and clinical learning could form critical thinking skills among students. Educational institutions play a role in providing training for clinical instructors oriented to improving the ability of students to provide scientific evidence-based nursing care. The clinical instructors are responsible for improving students' critical thinking skills through preceptorship and mentorship learning methods.
\end{abstract}

Keyword: critical thinking; mentorship; nursing; preceptorship

\section{Introduction}

Patients' demands on the quality of nursing services are increasing and a National Health Insurance $(\mathrm{JKN})$ system. Patients begin to be critical of the health services provided. All forms of nursing actions must be logically acceptable to the patient. This developmental situation then demands nurses to apply Evidence-Based Practice (EBP) in the provision of nursing care. Nurses must use the best and most recent research evidence in making decisions, nurse clinical experience, and patient choice (Boström et al., 2013) (Harun et al., 2019). Based on (Hart et al., 2008), implementing EBP is to provide the

\footnotetext{
*) Corresponding Author (Kurniati Puji Lestari)

E-mail: kurniati_pujilestari@yahoo.com
}

best service for patients. Based on this, several developed countries made EBP a top priority in health services.

Evidence-Based Practice (EBP) is currently the most recent issue in educational institutions and nursing services because it can provide compelling clinical evidence to improve the quality of nursing care (Zhang et al., 2019). Implementation of EBP depends on the ability of nurses as caregivers to clients. Previous studies have explained that nurses with higher qualifications can apply and value EBP values (Malik et al., 2015) (Gerrish et al., 2011). Supported by (Zeleníková et al., 2016) states that adequate nurses' knowledge and skills in conducting literature searches and critical assessments of research results are positive 
factors in the implementation of EBP. The development of knowledge and skills is preparing from the stage of higher education in nursing. (Dame Elysabeth; Gita Libranty;Siska Natalia, 2015) stated that the higher level of nursing education had an impact on the achievement of competencies in conducting EBP. Education can lead individuals to be more skilled in finding sources of research, organizing, being professional at work, increasing accesses to improving and implementing evidence-based nursing practice.

Nursing students to be more confident, intelligent, and skilled to engage in EBP in the future. This demand is a challenge for higher education institutions in nursing to prepare nursing students who have competence in the implementation of EBP. Changes that occur in nursing services in the clinical setting impact adjusting the curriculum of nursing education (Catherine V. Belden; Joan Leafman; Guy Nehrenz;Patricia Miller, 2012). It explained that EBP is the main competency that nurses must possess to improve patients' benefits so that it integrates into the nursing education curriculum. Research (Reid et al., 2017) explains that EBP module learning in nursing students impacts increasing self-confidence and implementation of EBP. Based on that, the integration of EBP into the nursing higher education curriculum is considered very important.

The implementation of EBP in Indonesia has not been fully implementing yet. The ability of nurses and nursing students to search, analyze and implement EBP is still limited. Research (Majid et al., 2011) showed that the implementation of EBP encountered obstacles, namely limited literacy, time, and good quality of research results. The ability of nursing students to understand EBP is also still low; this is supported by research by (Mehrdad et al., 2012), showing that nursing students' knowledge of EBP is still $47.1 \%$. Students' understanding of interpretation, journal criticism, and research applications is still low(Leach et al., 2016). (Legita, 2012) also mentioned that most nursing students $(69.7 \%)$ lack understanding of the concept of EBP. Based on these conditions, the increase in knowledge and skills in implementing EBP initiates the education stage earlier.

Nursing higher education institutions need to use practical approaches to enhance knowledge and skills in implementing EBP. The implementation of EBP is vital in building the nursing profession and integrating EBP in the nursing higher education curriculum through Student Center Learning (SCL) method. SCL is one method that approaches student learning processes to understand the construction process, consisting of receiving, organizing, storing, and being digested again by the mind through the active role of students in learning (Dong et al., 2019). (Kyriakoulis et al., 2016) The method has positively impacted the ability of EBP implementation included lectures, tutorials, workshops, seminars, journal clubs, and online sessions. Supported by (Ramis et al., 2018), several methods used in implementing EBP are lectures, group discussions, cooperative learning, problem-based learning, or a combination of several methods.

Learning methods that have a significant impact (Burgess et al., 2016) are role modeling learning. This method can integrate skills and positive attitudes towards the evidence-based nursing practice. Role models are essential for nursing students in understanding and imitating appropriate professional behavior (Benbassat, 2014). One model in this method is preceptorship and mentorship. Mentors become role models for nursing students in clinical learning (Wilson, 2014). An effective mentoring relationship is the exchange of knowledge, which supports the development between mentees and mentors (Eller et al., 2015) Whereas, clinical preceptorship in the study of (Burgess et al., 2016) to be able to increase student confidence in providing nursing care. The level of competence level is positively related to the interaction between the preceptor and the student.

Preceptorship and mentorship learning methods are applied based on constructivism theory. Through this theoretical approach, students construct knowledge independently to make a new understanding more meaningful (Kim et al., 2009). Constructivism theory will stimulate nursing students to find information, analyze, and conclude problem-solving to improve students' critical thinking skills in discussions using relevant Evidence (Budiman \& Septiawan, 2019). Critical thinking is the process of thinking to achieve goals that will provide reasons based on evidence, conceptualization, context, methods, and criteria (Larsson, 2017). Critical thinking is a component that students must possess in searching and processing information independently. While the concept of EBP is a strategy for finding scientific evidence, the ability to think critically in the implementation of EBP can be a determinant of the quality of nursing care. 
Good learning outcomes are closely related to the selection of appropriate learning methods. The choice of clinical learning methods can determine the quality of graduates. So tertiary nursing institutions need to know the correct approach to teach EBP-based nursing care. Based on this, the researcher identified the effect of implementing mentorship and preceptorship learning methods on the critical thinking skills of nursing students in providing EBP-based nursing care in a teaching hospital.

\section{Method}

The research design used was a quasiexperiment with the type of pretest and post-test with the control group. The population in this study were students of the nursing profession majoring in health polytechnic, Ministry of Health, Semarang. A total sample is 25 students for each intervention and control group based on sample calculations. The sampling method used is non-probability sampling with the purposive sampling technique. The inclusion criteria were nurses professional students who were undergoing clinical practice in primary nursing professions. The study was conducted in several teaching hospitals in Semarang in August 2019. The instrument used was a Student-evidence Based Practice Questionnaire with a validity value of $0.584-0.904$ and reliability of 0.821 developed by (Upton et al., 2012). The intervention is implementing during three weeks with the clinical advisory training stages (week 1), implementation of clinical guidance (week 2), and evaluation (week 3) - the implementation of clinical guidance was consist of pre conference, clinical direction, and post-conference. Clinical guidance methods used are bedside teaching, meet the expert, discovery learning. Evaluations are conducting in individual EBP seminars and Direct Observation of Procedural Skills (DOPS).

Univariate data analysis is described in frequency and percentage for the gender and mean and SD variables for nursing students' age and critical thinking variables. The normality test results with Kolmogorov-Smirnov data obtained critical thinking variables of nursing students were not normally distributed, with $\mathrm{p}=0.01(\mathrm{p}$ value $<0.05)$. Variance in sex data ( $\mathrm{p}$-value $=$ $0.129)$, age ( $\mathrm{p}$-value $=0.632$ ), and critical thinking of nursing students ( $\mathrm{p}$-value $=0.16$ ) are homogeneous. Bivariate data analysis using paired t-test and Wilcoxon test. Poltekkes
Kemenkes Semarang funded this research with a grant number HK.01.07 / 8.3 / 2856/2019. This study has received a certificate of passing the ethics test from the Health Research Ethics Commission of the Health Ministry of Health, Semarang, with 167 / EA / KEPK / 2019.

\section{Result and Discussion}

Table 1. Characteristics of nursing students by age $(n=52)$

\begin{tabular}{lcc}
\hline Variables & Mean \pm SD & Min-Max \\
\hline $\begin{array}{l}\text { Age } \\
\text { Intervention }\end{array}$ & $22.65 \pm 2.84$ & $21-34$ \\
\hline Control & $23.23 \pm 4.08$ & $21-40$ \\
\hline
\end{tabular}

Table 1. shows the mean values the age of nursing students in the intervention group was 22.65 with SD 2.84 and control group 23.23 SD 4.08 .

Table 2. Characteristics of nursing students based on gender $(n=52)$

\begin{tabular}{lcccc}
\hline \multirow{2}{*}{ Variables } & \multicolumn{2}{c}{ Intervention } & \multicolumn{2}{c}{ Control } \\
\cline { 2 - 5 } & $\mathrm{f}$ & $\%$ & $\mathrm{f}$ & $\%$ \\
\hline Gender & 5 & 19.2 & 3 & 11.5 \\
Male & 21 & 80.8 & 23 & 88.5 \\
Female & 26 & 100 & 26 & 100 \\
\hline Total & & & & \\
\hline
\end{tabular}

Table 2. illustrates the proportion of characteristics of nursing students by sex in the majority of women in the intervention group $(80.8 \%)$ and control $(88.5 \%)$.

Table 3. Description of critical thinking of nursing students $(n=52)$

\begin{tabular}{lccc}
\hline \multirow{2}{*}{$\begin{array}{l}\text { Critical } \\
\text { thinking }\end{array}$} & \multicolumn{3}{c}{ Intervention } \\
\cline { 2 - 4 } Pre-test & 98.54 & SD & $95 \%$ CI \\
Post-test & 106.69 & 11.25 & $93.99-103.08$ \\
\hline Critical & \multicolumn{3}{c}{ Control } \\
thinking & Mean & SD & $95 \%$ CI \\
\hline Pre-test & 105.19 & 16.01 & $98.72-111.66$ \\
Post-test & 112.96 & 14.87 & $106.95-118.97$ \\
\hline
\end{tabular}

Table 3 shows a description of the mean value of nursing students critical thinking before the intervention in the intervention group 98.54 with SD 11.25 and the control group 105.19 with SD 16.01. The average nursing students' critical thinking after the intervention in the intervention group 106.69 with SD 13.02 and the control group 112.96 with SD 14.87 . 
Table 4. Differences in critical thinking of nursing students

\begin{tabular}{lcccc}
\hline \multicolumn{1}{c}{ Group } & Mean & SD & MD & P value \\
\hline Intervention & & & & \\
Pre-test & 98.54 & 11.25 & 8.15 & 0.003 \\
Post-test & 106.69 & 13.02 & & \\
\hline Control & & & & \\
Pre-test & 112.96 & 16.01 & 7.77 & 0.009 \\
Post-test & 105.19 & 14.87 & & \\
\hline
\end{tabular}

Table 4 states that there are significant differences in critical thinking of nursing students before and after the intervention in the intervention group with a value of $p=0.003$ ( $p$ value $<0.05$ ) and a control group with a value of $\mathrm{p}=0.009(\mathrm{p}$-value $<0.05)$.

Table 5. Effect of training on nursing students' critical thinking

\begin{tabular}{lcccc}
\hline \multicolumn{1}{c}{ Group } & Mean & SD & MD & P-value \\
\cline { 1 - 3 } Intervention & & & & \\
Pre-test & 98.54 & 11.25 & 8.15 & \\
Post-test & 106.69 & 13.02 & & 0.006 \\
\cline { 1 - 2 } Control & & & & \\
Pre-test & 105.19 & 16.01 & 7.77 & \\
Post-test & 112.96 & 14.87 & & \\
\hline
\end{tabular}

Table 5 illustrates a significant influence of implementing the preceptorship and mentorship methods on critical thinking of nursing students with a value of $p=0.006$ ( $p$-value $<0.05$ ).

The implementation of the training program increases knowledge, skills, and positive attitudes as written (Mulyasa, 2003). Competencies consist of three aspects: cognitive, affective, and individual abilities to perform assigned tasks or jobs. Achievement of competencies through training and program development stages as an ongoing organizational program process. The training of the model of preceptors focuses on developing hands-on practice methods in the respective workplace of the perceiver with guidance. Nursing students need clinical learning methods that are capable of demanding active involvement to explore the ability to analyze a problem. (Wahl \& Thompson, 2013) Practical and creative teaching methods examine to facilitate and perfect critical thinking skills in nursing students-the competencies of hard skills and soft skills achieved through the preceptorship learning method at the clinical learning stage. One of the competencies soft skills that nursing students must possess is the ability to think critically. In a study conducted by (Mei Fitria Kurniati; Titih Huriah; Azizah Khiriyati, 2017), most students (81.8\%) could think critically with suitable criteria. The intervention group received a preceptorship method regularly and scheduled for three weeks. Students get the same opportunity to be able to follow the learning process accompanied by a preceptor. The forms of implementation of the preceptorship method are pre and post-conference activities and bedside teaching. Students discuss the patient's case starting from the assessment process, determining the nursing diagnosis, preparing a nursing action plan to choose the evaluation plan. Nursing students then conduct a post-conference with a discussion accompanied by a preceptor using critical thinking analysis (Lestari et al., 2019).

During the clinical learning process, trained receptors provide learning situations that encourage students to find solutions to one problem by finding and gathering information and analyzing relevant information through critical thinking. Students who can think critically will integrate theory into practice and be more sensitive and understand (Dina Alfiana Ikhwani; Wiwik Kusumawati; Moh Afandi, 2018). Factors that influence the implementation of EBP by nursing students, according to (Ashktorab et al., 2015) including the intention, knowledge, attitude, and behavior of nursing students. Of the three factors, the attitude of students in implementing EBP is a factor that strongly supports the implementation of EBP. To realize this, the introduction of EBP is an effort that educational institutions must make to improve the knowledge and attitudes of students so that they can support the application of EBP in clinical practice.

Based on (Ryan 2016), several intrinsic and extrinsic factors are associated with implementing EBP in nursing students. Intrinsic factors are the intention, knowledge, and attitude of nursing students. Outside factors are related to organizational and institutional organizational support, such as the facilitator or mentorship's ability to provide direction for implementing evidence in clinical practice, the availability of supporting facilities, and environmental support. The results of this study are consistent with the research (Mei Fitria Kurniati; Titih Huriah; Azizah Khiriyati, 2017), which states that there are differences in the ability to think critically after getting the method of preceptorship with the technique of pre and post-conference. Supported by research (Zeleníková et al., 2016) reported that adequate nurses' knowledge and skills in conducting literature searches and 
critical assessments of research results increased after implementing EBP results in clinical practice. The development of knowledge and skills prepare from the stage of higher education in nursing. Nursing students are the main actors to support the implementation of EBP in the future.

Based on research (Legita, 2012), most students $(69.7 \%)$ did not understand the concept of EBP. Under these conditions, an increase in knowledge and skills in implementing EBP since it is still in the stage of tertiary education is considered very necessary. This research result same with (Suprapti, 2020) which states that based on training participants' perceptions of the preceptor training model, the impact on competency mix has a significant effect. The better the participant's perception of the implementation of the training model, the better the participant's perception of competency achievement. (Zadeh et al., 2014)explains that evidence-based and critical thinking are two complementary things. Critical thinking is an essential part of directing students or nurses in making clinical decisions or implement EBP. The application of EBP is possible to improve critical thinking in searching, analyzing, synthesizing, and making decisions from various available information. Quality nursing services are very concerned about scientific, cultural, and technological developments. The formation of these capabilities requires forming the preceptor's professional character through training, continuous education improvement in shaping intellectual, technical, and interpersonal skills, working based on standards of practice, paying attention to ethical and moral rules. Preceptors are increasing the self-confidence of Nurse Professional students using Evidence Based Practice in interpreting, analyzing, explaining, and inferencing in finding information.

Preceptorship is a clinical learning method that has the potential to facilitate students to encourage reflection and improve critical thinking skills (Sulung, 2016). The limitation of this research is the respondents of the intervention group is students who practice in the type B teaching hospital, while the respondents in the control group are students who practice in the type A teaching hospital. The questionnaire was filled out independently by the students so that the results of the data collection were subjective. Assessment in future research can be carried out by clinical instructors objectively using predetermined evaluation sheets.

\section{Conclusion and Suggestion}

Implementation of preceptorship and mentorship clinical learning methods can improve the critical thinking skills of nursing students in providing EBP-based nursing care. The clinical counselor is responsible for facilitating students in achieving predetermined clinical competencies, critical thinking in providing EBP-based nursing care. Component nursing students can master three essential aspects of the clinical learning process: knowledge, attitudes, and skills. Clinical instructors in carrying out their duties and responsibilities through training on implementing EBP to increase the capacity to direct, facilitate and assist nursing students in interpreting EBP in the provision of nursing care. Educational institutions play a role in providing training for clinical counselors oriented to improving the ability of students to achieve clinical competence.

\section{Acknowledgments}

Thanks to the Health Polytechnic of Ministry of Health in Semarang as a research grant provider, Indonesian Nursing Association of Central Java Province, KRMT Wongsonegoro General Hospital Semarang, clinical instructors, and nursing students.

\section{References}

Ashktorab, T., Pashaeypoor, S., Rassouli, M., \& Alavi-Majd, H. (2015). Nursing Students' Competencies in Evidence-Based Practice and Its Related Factors. Nursing and Midwifery Studies, 4(4). https://doi.org/10.17795/nmsjournal23047

Benbassat, J. (2014). Role modeling in medical education: The importance of a reflective imitation. Academic Medicine, 89(4), 550-554. https://doi.org/10.1097/ ACM.0000000000 000189

Boström, A., Rudman, A., Ehrenberg, A., Gustavsson, J. P., \& Wallin, L. (2013). Factors associated with evidence-based practice among registered nurses in Sweden: a national cross-sectional study Anne-Marie. BMC Health Services Research, 13(165), 1-12.

Budiman, A., \& Septiawan, T. (2019). Pengaruh Penerapan Evidence Based Practice 
Terhadap Kemampuan Berpikir Kritis Mahasiswa S1 Keperawatan. PROFESI (Profesional Islam): Media Publikasi Penelitian, 17(1), 1-7. ejournal.stikespku.ac.id

Burgess, A., Oates, K., \& Goulston, K. (2016). Role modeling in medical education: The importance of teaching skills. Clinical Teacher, 13(2), 134-137. https://doi.org/10.1111/tct.12397

Catherine V. Belden; Joan Leafman; Guy Nehrenz;Patricia Miller. (2012). The Effect of Evidence-Based Practice on Workplace Empowerment of Rural Registered Nurses. Journal of Rural Nursing and Health Care, 12(2), 64-76.

Dame Elysabeth; Gita Libranty;Siska Natalia. (2015). Correlation between nurse's education level with the competency to do the evidence-based practice. Jurnal Skolastik Keperawatan, 1(1), 14-20.

Dina Alfiana Ikhwani; Wiwik Kusumawati; Moh Afandi. (2018). Pengaruh evidence-based practice terhadap critical thinking mahasiswa keperawatan di stikes mataram. Repository Universitas Muhammadiyah Yogyakarta.

Dong, Y., Wu, S. X., Wang, W., \& Peng, S. (2019). Is the Student-Centered Learning Style More Effective Than the Teacher-Student Double-Centered Learning Style in Improving Reading Performance? Frontiers in Psychology, 10(November). https://doi.org/10.3389/fpsyg.2019.02630

Eller, L. ., Lev, E. ., \& Feurer, A. (2015). Key components of the effective mentoring relationship. Nurse Educ Today, 27(3), 320331.

https://doi.org/10.1016/j.nedt.2013.07.020. Key

Gerrish, K., Mcdonnell, A., Nolan, M., Guillaume, L., Kirshbaum, M., \& Tod, A. (2011). The role of advanced practice nurses in knowledge brokering as a means of promoting evidence-based practice among clinical nurses. Journal of Advanced Nursing, 67(9), 2004-2014.

https://doi.org/10.1111/j.13652648.2011.05642.x

Hart, P., Eaton, L. A., Buckner, M., Morrow, B. N., Barrett, D. T., Fraser, D. D., Hooks, D., \& Sharrer, R. L. (2008). Effectiveness of a computer-based educational program on nurses' knowledge, attitude, and skill level related to evidence-based practice. Worldviews on Evidence-Based Nursing, 5(2), 75-84. $\quad$ https://doi.org/10.1111/j.1741- 6787.2008.00123.x

Harun, H., Herliani, Y. K., \& Setyawati, A. (2019). Pengetahuan, Sikap Dan Kesiapan Mahasiswa Program Profesi Ners Dalam Penerapan Evidence Based Practice. Jurnal Perawat Indonesia, 3(2), 117. https://doi.org/10.32584/jpi.v3i2.309

Kim, S. C., Brown, C. E., Fields, W., \& Stichler, J. F. (2009). Evidence-based practice-focused interactive teaching strategy: A controlled study. Journal of Advanced Nursing, 65(6), 1218-1227. https://doi.org/10.1111/j.13652648.2009.04975.x

Kyriakoulis, K., Patelarou, A., Laliotis, A., Wan, A. C., Matalliotakis, M., Tsiou, C., \& Patelarou, E. (2016). Journal of Educational Evaluation for Health Professions Educational strategies for teaching evidence-based practice to undergraduate health students: a systematic review. J Educ Eval Health Prof, 13(34), 1-10. http://dx.doi.org/10.3352/jeehp.2016.13.3 4

Larsson, K. (2017). Understanding and teaching critical thinking-A new approach. International Journal of Educational Research, 84(December 2016), 32-42. https:/ / doi.org/10.1016/j.ijer.2017.05.004

Leach, M. J., Hofmeyer, A., \& Bobridge, A. (2016). The impact of research education on student nurse attitude, skill and uptake of evidence-based practice: A descriptive longitudinal survey. Journal of Clinical Nursing, 25(1-2), 194-203. https://doi.org/10.1111/jocn.13103

Legita, T. (2012). Pengetahuan, Sikap dan Kesiapan Perawat Klinisi Dalam Implementasi Evidence-Base Practice. NERS Jurnal Keperawatan, 8(1), 84. https://doi.org/10.25077/njk.8.1.8497.2012

Lestari, K. P., Siswanto, J., Sriningsih, I., \& Setyowati, S. E. (2019). Pelatihan Instruktur Klinik: Metode Perseptor Dalam Pembelajaran Klinik Di Lingkungan Dinas Kesehatan Kota Semarang. Link, 15(1), 7. https://doi.org/10.31983/link.v15i1.3923

Majid, S., Foo, S., Luyt, B., Zhang, X., Theng, Y. L., Chang, Y. K., \& Mokhtar, I. A. (2011). Adopting evidence-based practice in clinical decision making: Nurses' perceptions, knowledge, and barriers. Journal of the Medical Library Association, 99(3), 229-236. https:/ / doi.org/10.3163/15365050.99.3.010 
Malik, G., McKenna, L., \& Griffiths, D. (2015). An Analysis of Evidence-Based Practice Curriculum Integration in Australian Undergraduate Nursing Programs. GSTF Journal of Nursing and Health Care, 3(1). https://doi.org/10.5176/2345-718x_3.1.104

Mehrdad, N., Joolaee, S., Joulaee, A., \& Bahrani, N. (2012). Nursing faculties' knowledge and attitude on evidence-based practice. Iranian Journal of Nursing and Midwifery Research, 17(7), 506-511.

Mei Fitria Kurniati; Titih Huriah; Azizah Khiriyati. (2017). Perbedaan tingkat kemampuan berfikir kritis dan kemampuan leadership pada mahasiswa dengan metode preceptorship. Repository Universitas Muhammadiyah Yogyakarta. https:/ / ci.nii.ac.jp/naid/40021243259/

Mulyasa. (2003). Kurikulum Berbasis Kompetensi, Konsep, Karakteristik dan Implementasi. Remaja Rosda Karya.

Ramis, M. A., Chang, A., \& Nissen, L. (2018). Undergraduate Health Students' Intention to Use Evidence-Based Practice After Graduation: A Systematic Review of Predictive Modeling Studies. Worldviews on Evidence-Based Nursing, 15(2), 140-148. https://doi.org/10.1111/wvn.12268

Reid, J., Briggs, J., Carlisle, S., Scott, D., \& Lewis, C. (2017). Enhancing utility and understanding of the evidence-based practice through undergraduate nurse education. BMC Nursing, 16(1), 1-8. https:/ / doi.org/10.1186/s12912-017-0251-1

Ryan, E. J. (2016). Undergraduate nursing students' attitudes and use of research and evidence-based practice - an integrative literature review. Journal of Clinical Nursing, 25(11-12), 1548-1556. https:// doi.org/10.1111/jocn.13229

Sulung, N. (2016). Efektifitas Metode Preseptor dan Mentor dalam Meningkatkan Kompetensi Perawat Klinik. Jurnal IPTEKS Terapan, https://doi.org/10.22216/jit.2015.v9i3.416

Suprapti, F. (2020). Factors Related to Practice, Attitude and Skill of Nurses to Evidence-Based Practice in the Hospital. 30(Ichd), 380-384. https://doi.org/10.2991/ahsr.k.201125.065

Upton, P., Scurlock-Evans, L., Stephens, D., \& Upton, D. (2012). The adoption and implementation of evidence-based practice (EBP) among allied health professions. International Journal of Therapy and Rehabilitation, 19(9), 497-503. https://doi.org/10.12968/ijtr.2012.19.9.497

Wahl, S. E., \& Thompson, A. M. (2013). Concept mapping in a critical care orientation program: A pilot study to develop critical thinking and decision-making skills in novice nurses. Journal of Continuing Education in Nursing, 44(10), 455-460. https://doi.org/10.3928/0022012420130916-79

Zadeh, H. H., Khajeali, N., Khalkhali, H., \& Mohammadpour, Y. (2014). Effect of evidence-based nursing on critical thinking disposition among nursing students. Life Science Journal, 11(9 SPEC. ISSUE), 487-491.

Zeleníková, R., Gurková, E., Žiaková, K., Tomagová, M., Jarošová, D., \& FineoutOverholt, E. (2016). Psychometric Properties of the Slovak and Czech Versions of the Evidence-Based Practice Beliefs and Implementation Scales. Worldviews on Evidence-Based Nursing, 13(2), 139-152. https://doi.org/10.1111/wvn.12128

Zhang, Y. P., Liu, W. H., Yan, Y. T., Zhang, Y., Wei, H. H., \& Porr, C. (2019). Developing Student Evidence-Based Practice Questionnaire (S-EBPQ) for undergraduate nursing students: Reliability and validity of a Chinese adaptation. Journal of Evaluation in Clinical Practice, 25(4), 536-542. https://doi.org/10.1111/jep.12897 